\title{
SEMANTIC SYNCRETISM IN THE UZBEK LANGUAGE AS A REPRESENTATION OF THE COLOR "BLACK"
}

\author{
Tojiyev Alimjon Muydinovich
}

Candidate Of Philological Sciences,Docent Andijan State University, Uzbekistan

\section{ABSTRACT}

This article provides information about the breadth of semantic field of black lexemes in the Uzbek language, the existing such phenomena polysemantic, metaphorical, metonymic, enontesemic, occasional, pragmatic, connotation representing syncretic phenomena in its lexical nature. The black lexeme can illuminate semantic syncretism in the mantle structure in addition to its usual meaning together with the lexemes to which it is attached.

KEYWORDS: - Syncretism, polysemantics, metaphor, metonym, connotation, pragmatics, usual meaning, denotative meaning, significative meaning.

\section{INTRODUCTION}

It is known from history that the word black is defined among the Turkic people, including the Uzbek people, as a symbol of humility, immorality, evil, wickedness, cruelty. Along with other Turkic peoples, Uzbek folk tales, fairy tales, legends, riddles and proverbs depict only the representation of a bad, evil, lowly person. We mentioned on this above.

Each nation has its own association of color choices. In the Uzbek people, the associative semantic field associated with the word black is wider than the word white. Analyzes show that the width of the semantic field of black is also widely expressed in the expression of phrasal verbs, phrases associated with somatism. This semantic field is the nation's attitude towards black in the world landscape, a vivid expression of national mentality, everyday life and culture in language. In other words, in folklore and fiction, the semantic structure of the word black refers to the "syntagmatic" appearance of a stable attributive compound. The breadth of the semantic field of the word black cannot be said to be coincidental.

The word black is a polysemantic word and occurs as a result of the word shifting to a figurative meaning in its semantic structure. According to G.H.Bukharova: "With the help of lexemes meaning color, it is possible to express not only color, but also some idea, thought, information ${ }^{1}$. Thinking that a reality is related to something or an event, according to popular belief, also leads to the formation of a figurative meaning, that is to say, to the emergence of a polysemantic word ${ }^{2}$. Analyzing the semantic

\footnotetext{
1 Бухарова Г.Х.Башкирский народный эпос «УралБатыр»:когнативно -дискурсивный и концептуалный анализ:дисс....д.филол.н.Уфа,2009.С.207.

2 Ўзбек тили лексикологияси.-Т.,ФАН.1981.283-бет.
} 
CURRENT RESEARCH JOURNAL OF HISTORY 2(10): 03-09, October 2021

DOI: https://doi.org/10.37547/history-crjh-02-10-02

ISSN 2767-472X

(C)2021 Master Journals

\section{Crossref do) 81 Google}

Accepted 05th October, 2021 \& Published 10 ${ }^{\text {th }}$ October, 2021

structure of white and black words in the Kumuk language, D.A.Arslanbekova notes: "In Turkic and Mongolian languages, the black name is a lexical name which expresses various negative attitudes:" unhappy "," tormenting "," darkness "," suffering "," immorality "," naughty"," cunning "and others. ${ }^{3}$.

The Explanatory Dictionary of the Uzbek Language contains explanations of thirteen types of meanings of the black lexeme and defines them in combination with other meanings. It turns out that the word black was used in a negative sense as a sign of bad, filthy, ugly, degrading and immoral. In Uzbek folk tales, fairy tales and legends, riddles and proverbs, the images associated with the word black were an expression of humility. However, the historical sources studied, as well as the analysis, show that the black lexeme is a broad lexeme with a semantic field that represents not only a negative meaning but also a positive meaning. According to A.N.Kononov, in Turkic languages (azarb.turkm.gara) the word black has the following meanings: 1) black, dark, sad, hard, sorrowful, unhappy. 2) black cattle, crowd, people, army. 3) land, earth. 4) hill, height, high hill ${ }^{4}$. It has been clear that the semantic field of the black lexeme was wide in the early periods, but later this field expanded even more.

Apparently, in the process of studying the historical valence dynamics of color words in Turkic languages, including Uzbek, it can be said that lexical-semantic changes of words also apply to groups of words. The direct involvement of colors in the naming of an objective being serves

\footnotetext{
${ }^{3}$ Арсланбекова Д.А.Прилагательные къара"черный” и акъ “белый” в блогопожеланиях и проклятиях отемишского говора кумыкского языка.https://lib.herzen.spb.ru>arslanmekova_11_ 32_ 17 _ 20

${ }^{4}$ Кононов А.Н. Семантика
}

to reveal the meanings inherent in the national mentality. Color-expressing lexemes have long been composed of their own denotative zones and have been reflected in all of the abovementioned historical lexicological research. However, it should be noted that the fact that the history of lexical-semantic groups of color expression is still not widely studied by researchers shows the urgency of the issue. In other words, the formation of valence by colorexpressing lexemes can reveal a wide range of semantic relationships in language. This is because the direct occurrence of lexical valences forms word combinations. It provides ample opportunity to reveal the semantic syncretism in it.

Concepts represented in black emerge in connection with connotation. Connotation encompasses phenomena related to different concepts and reveals specific aspects in the semantic structure of the word black. It should be noted that the existence, diversity, stability of connotation in the language is a testament to the richness of the language, the possession of ancient traditions, the boundless possibilities of expression, the sharpness of the impact and image power. ${ }^{5}$.

In Turkic peoples, including the Uzbek people, the names of individuals, which are represented in black, are still used as national spirituality, customs and religious concepts. For example, Qorako'z, Qoratoy, Qorajon, Qoraxoja, Qorasoch, Qorabosh, Qoraxon, Qorabola, Qorabotir, Qorachaxon. It should be noted that the names of these people have hidden meanings in addition to the meanings which they have expressed. The study and analysis of the etymology of words shows that the meaning in color symbols may change in different peoples at different times.

\footnotetext{
${ }^{5}$ Махмудов Н.Тил тилсими тадқиқи.-Тошкент,Mumtoz so’z.2017.-Б.22.
} 
CURRENT RESEARCH JOURNAL OF HISTORY 2(10): 03-09, October 2021

DOI: https://doi.org/10.37547/history-crjh-02-10-02

ISSN 2767-472X

(C)2021 Master Journals

\section{Crossref do) 81 Google}

Accepted 05th October, 2021 \& Published 10 ${ }^{\text {th }}$ October, 2021

Because over time, the original core meaning will be able to express a different meaning according to its inner nature, that is to say, it will be able to expand the scope of meaning. For example, the word black is a word that has a negative status by nature. However, the breadth of its semantic field also reflects the positive (black - bad, dirty; black - big, great). This is clearly reflected in the text.

Qorako'z lost consciousness due to heavy blows to the head and time healed him (M.Norboeva) (Қоракўз бошида ўтган оғир зарбалар туфайли ўзини бирмунча йўқотиб қўйди, вақт унга шифо ато этди). Now his eyes were a little lighter than before, his deadly black eyes began to move, and his blood-red faces were open. (Энди бояғиға қараганда бир оз ениллангансумон,жон олғучи қора кўзлари харакатлана бошланған,бўриқ қан қизил юзлари очилинқираған эдилар) (А.Қодирий). The chairman was happy for the wedding and came in a good mood when he felt blue seeing Qoratoy (Раис туйга хурсанд бўлиб, яхши рух билан келган эди, Қоратойни кўриб яна рухи тушиб кетди (М.Қориев). Rakhmatjon aka intended to give a "black colt" as a gift to his grandson's khatna tuy (from the newspaper). (Рахматжон ака неварасининг хатна тўйига “қора той” совға қиламан деб ният қилган эди (Газетадан). The blacksmith intended to try not to meet strangers and to avoid himself (M.Osim). (Қорасоч номахрамларга рўпарў келмасликка харакат қилмоқ ва ўзини назардан четга олмоқ ниятида эди (М.Осим).Mahbuba braided her long black hair to her mother, put on a atlas dress and hurried to visit (A.Abdullaev). (Махбуба узун қора сочларини онасига ўрдириб, атлас кўйлагини кийиб, мехмонга боришга ошиқди (А.Абдуллаев). Qorabosh planned to pick the fruit from the garden and take it to the market and sell it for more money (M. Niyazov).(Қорабош боғдаги меваларни йиғиштириб, бозорга олиб бориб дадилроқ пулга сотишни режалаштирди(М.Ниёзов).As Qorabosh came out the cave alone from the heart of Rangontog and it realized that it had no choice and surrender to fate. (Ёлғиз Қорабош судралганча Рангонтоғ бағридаги ғордан чиқиб ўзини тақдир хукмига топширмоқдан ўзга иложи йўқлигини фахмлади (Ш.Бўтаев). In folk medicine, the benefits of buckwheat (qorabosh) for humans have not yet been mentioned (from the newspaper). (Халқ табобатида қорабошнинг инсон учун фойдали томонлари хали айтилмаган (Газетадан). Qorabola felt that he missed her children with all his body now ( $\mathrm{T}$. Ashurov).(Қорабола бутун вужуди билан болаларини соғинганини энди хис этди (Т.Ашуров).

Grooms' work has always a lot: put the hay, clean the horse, barn, and so on. The "Qorabola (black boy)" was in charge (M. Niyazov). (Отбоқаларнинг иш-юмушлари хамиша бошларидан ошиб ётади:хашак сол, отини тозала, қашла, совит буларнинг барчаси “қора бола" зиммасида эди (М.Ниёзов). Qarabotir waited for the appropriate time to execute his shell intentions in order to become united with Zuhrakhan (Tahir and Zuhra dos). Қоработир Зухрахонга етмоқ ниятида ўз қабиғ ниятлари амалга ошириш учун пайт пойлади (Тохир ва Зухра дос). Both of them were tipsy and cussed their head off.

- Hey, look at me, Qorabotir lost his senses, I signed yesterday's (M.Koriev). (Иккиси хам яхшигина кайф қилишган, оғзидан боди кириб шоди чиқади.

- Хей, менга қара, “Қора ботиринг”нинг мияси ачиб қолибди, кечагига хам боплаб қўл қўйдириб олдим (М.Қориев).

In the first sentence quoted, the Qorako'z lexeme is used in the meaning of a person. Qorako'z is female name: Qarako'z, Qarakoz (uzb.) which 
CURRENT RESEARCH JOURNAL OF HISTORY 2(10): 03-09, October 2021

DOI: https://doi.org/10.37547/history-crjh-02-10-02

ISSN 2767-472X

(C)2021 Master Journals

\section{Crossref do) 81 Google}

Accepted 05th October, 2021 \& Published 10 ${ }^{\text {th }}$ October, 2021

means beautiful, handsome child with black eyes. In the second sentence, the combination of black eyes expresses a somatic meaning which is a visual organ of the person. It also combines beautiful, captivating meanings. Linguist E.A.Begmatov in his dictionary "Uzbek names" explains the meaning of the names of people given in the above sentences as follows:

Qoratoy (Uzbek) -a child like a foal (1-year-old foal), that is to say, a child who grows up playing and enjoy like a foal, or a qora(black) + toy (foal) is strong, powerful and beloved. hair.

Qorasoch (*., Eng.) - a girl with dark hair, bell

Qorabosh (Uzbek) - a slave, a maid or an eagle or a child with dark hair.

Qorabola (Uzbek) - a strong, powerful child or a child of black color (from black), which became a nickname later.

Qorabotir (Uzbek) - strong, powerful, brave; brave boy ${ }^{6}$.

In "Devonu lug'atit turk", the name Qorabosh is defined as follows: Qorabosh is a name given to slaves, both male and female. Black means head ${ }^{7}$. The "Qoratoy" in the following sentences is a gift for a tamed pet, grandson and children's xatna tuy (grandson' wedding); "Qorasoch", "Qorabosh" in somatic units "black hair" is a fiber in the human head; The word "qorabosh" has two meanings: the name of a wild animal is a secondary name and the name of a plant is a third name. Qorabosh is a dark-flowered, thickstemmed rock. The combinations "Qorabola" and "Qorabotir" have a creative, occasional meaning. It is understood that the "qora bola (black boy)" is the nickname of the person who does black works. The term "Qorabotir" means a person

\footnotetext{
6 Яна қаранг:Шу муаллиф.Ўша луғат.546-бет.

Қошғарий М.Девону луғатит турк .Уч жилдлик, Учинчи жилд.-Т., Фан.1963.241-бет.
}

who puts a barrier to those who put their interests above the interests of the people. It should be noted that Qorabotir is also used in folklore as a symbol of evil. However, both nicknames have something in common with a person's character, physical and mental maturity. It is a product of creativity.

It has been clear that signs are a broad concept which can be interpreted differently, representing complex meanings, indicating the complexity of meaning, the multiplicity of meanings and the presence of points of intersection with each other. It is understood that this is reflected in the language of that nation, which is the expression of the national culture, spirituality, national mentality of each nation.

The nature of a word is not always the same, because the generalizing word has the power to express a number of signs of objects and events over time, to mean many meanings, to articulate other concepts on the basis of one concept. to Prof.N.Mahmudov noted: "There is no language on earth, there is no spiritual shift in its various units, it can be said that the semantic structure of all units is completely rigid, there is a language consisting only of units specific to one meaning not ${ }^{8}$. In different nations of the world, "Black is a symbol of mourning, infinity, fear, death, abstraction, while red is a symbol of victory, joy, happiness, life, fire and blood." In all times, people have lived in fear of the darkness. The difficult periods of a person's life are also described as their "dark days".

The black landscape in the picture of the universe shows the existence of syncretism in

\footnotetext{
8 Махмудов Н.Зиддият ва маъно тараққиёти// Ўзбек тили ва адабиёти.-Тошкент,2014.-3-сон.-Б.19.

43Ў танова С. Алишер Навоий ғазалиётида ранг символикаси. - Тошкент: Tafakkur,

2011. - Б.19.
} 
CURRENT RESEARCH JOURNAL OF HISTORY 2(10): 03-09, October 2021

DOI: https://doi.org/10.37547/history-crjh-02-10-02

ISSN 2767-472X

(C)2021 Master Journals

\section{Crossref dof 81 Google}

Accepted 05th October, 2021 \& Published 10 ${ }^{\text {th }}$ October, 2021

the nature of the connection of "black", "shadow", "night" in ancient myths. For example, the connection of the Earth with black, the connection of the Sky with blue, is reflected in the concept of man as a symbol of color. The breadth of the semantic field of color in any language has a combination of positive and negative evaluation meanings. Literary scholar D.Tadjibayeva observes the work of H. Davron and writes: "In the work of Khurshid Davron, black has a special symbolic meaning. In the poem, which begins with "Fearless black night"("Қўрқмай кир қора тунга"), the color black does not mean fear, considering the difficult days, hard times, struggles and hardships of human life:

Қўрқмай кир қора тунга,

Гарчи ўтмоғинг қийин,

Хеч ким бас келмас сенга

Тундан ўтгандан кейин .

(Fearless dirty black night,

Although difficult to pass,

No one will stop you

After midnight) (Х.Даврон)

The poem calls for a "black night." "Black Night" is a path of struggle, heroism, courage and bravery. "Indeed, if we develop the ideas cited by the scholar, the black lexeme in our language itself expands the semantic field with the lexemes with which it is associated. Apparently, there is an internal contradiction in the black lexeme itself. The poet took a creative approach to the combination of "black night" with a philosophical emphasis. The combination of "black night" used by the poet represents the figurative meaning. The original meanings of the black and night lexemes are darkness and low vision. However, the night lexeme also has the meaning of time. Hence, both lexemes combine to form meanings which contradict their denotative meanings. Action and the emergence of the situation towards the positive. This positivity reveals a connotative meaning.

The Russian scientist E.N.Panov writes: "Language consists of a complex system of signs. Characters included in this system can represent objects and events in the real world in an unlimited way.

When all the signs of a language come together, they create a separate general picture of the people who live and create something. That is why people's lifestyles and social status are so diverse. They also differ from each other" 9

Along with other languages in the system, we can observe the connotative association associated with black in a number of Turkic languages, including Uzbek. For example, 1. Botaboy Mirsalim would always be happy with his father's kindness when he asked him how he was. But once Botaboy remembered his father's words that when you are old, you think about the hereafter, thinking that our destination is a black land and you accept the reluctance (S. Anorboev). 2. The woman who makes the earth a woman, and the woman who makes the land black (Proverbs). I am the same black man who feeds, clothes and carries a human child (M. Qoriev).

In the first sentence, the compound black earth was used as a lexeme to generalize the semantics of the euphemistic grave meaning of man's final address, while in the second sentence the earth's semantics, which destroys man's masculinity, oriya, and pride in front of others. In the third sentence, the combination of black earth signifies a positive evaluation relationship, meaning that

\footnotetext{
${ }^{9}$ Панов Е.Н.Знаки.Символи.Языки.-М.:Знание.1980.C.38.
} 
CURRENT RESEARCH JOURNAL OF HISTORY 2(10): 03-09, October 2021

DOI: https://doi.org/10.37547/history-crjh-02-10-02

ISSN 2767-472X

(C)2021 Master Journals

\section{Crossref do) 81 Google}

Accepted 05th October, 2021 \& Published 10 ${ }^{\text {th }}$ October, 2021

human life is the basis of all relationships in lifestyle. As the linguist A.Sobirov points out rightly, since things in the universe have their permanent attributes, human compares things and events using the powerful weapon given to them and draws conclusions about their differences, peculiarities, judgments.

It is understood that the color expression of black earth reflects not only the classification of the world around us, but also through the color expression the author emotionally reflects their attitude to adersant. The breadth of possibilities of subjective connotation is manifested in the process of expressing the opposite meaning of a word. Connotation is always associated with the pragmatic aspect of the text, representing an expressive image to it.

Late in the evening the boss came on horse. After seeing the blackness of the boss, we worked harder (G. Gulom). At that moment, Mahvash had something like a fist in the throat. He became dejected. He was going to cry. It would hurt him to get rid of the "black" in his heart, to forget everything (T. Ashurov). If Muzaffar Aminovich had a "black" in his place of work, there was no need for leadership elsewhere (from the newspaper). When you see the word black in the quoted sentences, it combines with the words to remove and reveals different meanings. That is to say, when you see black, the combination is in the form of a noun + verb with the possessive and accusative suffixes which means the appearance of the person, the approach to the object, the image. M. Sodikova writes that the word "black" is used in the sense of "pupil", "silhouette", "shadow", "human" and sometimes "target", "orientation"."11.

\footnotetext{
${ }^{10}$ Собиров А.Ўзбек тилининг лексик сатхини системалар системаси тамойили асосида тадқиқ этиш.--Т.:Маънавият.2004..69-бет.

${ }^{11}$ Содиқова М.Хозирги ўзбек тилида сифат.-Т.,ЎзССР
}

Analyzes show that the word black can express implicit (hidden) meanings in addition to its own meaning, expanding the semantic field of the word "black" with the word with which it is attached. Thus, the combination of "black" is also used by the artist in a metaphorical sense, revealing the semantics of "dark past", "dark days", "hard life". Whether the word "black" in the next sentence, combined with the incomplete verb which realizes the pragmatic meanings of "even," "assimilation," "immorality" and so on.

It is known that the pupil associated with the human body exhibits pragmatic meanings creating syncretic metonymy in the mantle structure. In the mantle, the non-human meanings completely change the meaning of the sentence. For example, the doctor told Mahbuba that the blow did not affect on the pupil. Muqaddas didn't trust to anyone taking great care of like the pupil of eyes Yodgor's savings and if she believed to someone, she was afraid of being separated with him.

In the above sentences, the pupil combination in the first sentence occurs in the usual sense, that is to say, the association with the human body. The organ that represents the image of the human world to see, feel, imagine the being.

In the second sentence, the pupil expresses a signifier and creates associations in our memory, such as trust, dignity, fidelity, loyalty, faith. also represents possible pragmatic meanings. For example, apple of one's, apple of one's and others. In the first example the phrase quoted above apple of one's eye meant to love Motherland, to protect it, to devote one's life to it; the second example is a syncretic metonymy that combines semaphores such as the preservation, protection and conscience of each person's human characters.

Each word within the semantic field is 
CURRENT RESEARCH JOURNAL OF HISTORY 2(10): 03-09, October 2021

DOI: https://doi.org/10.37547/history-crjh-02-10-02

ISSN 2767-472X

(C)2021 Master Journals

\section{Crossref dof 81 Google}

Accepted 05th October, 2021 \& Published 10th October, 2021

considered as the smallest element of that group and its meaning is determined on the basis of the relative relation of which word to other words within that group. 12

It is understood that the semantic field of the pupil compound is a lexeme of a broad with syncretic nature.

It is clear that as a word in a language can be a term for more than one thing-phenomena (polysemy), there is a situation where a certain thing- phenomena can express more than one word. It is self-evident that the new meaning of the word always arises not only from the demand for the expression of new things, but also from the demand for the expression of existing things. ${ }^{13}$

\section{Conclusion}

In conclusion, in the process of investigating color expression in language, we observed that it is a specific system which exists not only a semantic field and microsystem in general linguistics, but also a specific semantic field and microsystem in private linguistics. On the one hand, the central "basis" of this system is color representation, on the other hand, the words around the word representing color with their different shades of meaning, express multiple meanings and create semantic syncretism. It is understood that both white and black lexemes representing color also consist of a specific microsystem which forms the semantic field of lexemes representing different meanings around them.

\section{ReFERENCES}

1. Бухарова Г.Х.Башкирский народный эпос «Урал-Батыр»:когнативно -дискурсивный и концептуалный анализ:дисс....д.филол.н. Уфа, 2009.

2. Ўзбек тили лексикологияси. Т.,ФАН.1981.

3. Арсланбекова Д.А.Прилагательные къара"черный” и акъ “белый” в блогопожеланиях и проклятиях отемишского говора кумыкского языка.https://lib.herzen.spb.ru>arslanmeko va_11_32_17_20.

4. Махмудов Н.Тил тилсими тадқиқи. Тошкент: Mumtoz so'z.2017.

5. Қошғарий М.Девону луғатит турк .Уч жилдлик,Учинчи жилд. - Т.: Фан.1963.

6. Махмудов Н.Зиддият ва маъно тараққиёти// Ўзбек тили ва адабиёти.Тошкент, 2014.-3-сон.

7. Ўтанова С. Алишер Навоий ғазалиётида ранг символикаси. - Тошкент: Tafakkur, 2011.

8. Панов Е.Н.Знаки.Символи.Языки. -М.: Знание.1980.

9. Собиров А.Ўзбек тилининг лексик сатқини системалар системаси тамойили асосида тадқиқ этиш. - Т.: Маънавият.2004.

10. Содиқова М.Хозирги ўзбек тилида сифат. - Т.: ЎЗССР ФАН.1974.

${ }^{12}$ Собиров А.Кўрсатилган китоб.70-бет.

${ }^{13}$ Ўзбек тили лексикологияси.-Т.,ФАН.,1981.234-бет. 